\title{
Morphological and Numerical Characteristics of the Southern Chinese Dentitions. Part II: Traits in the Permanent Dentition
}

\author{
Nigel M. King ${ }^{*}, 1$, Jennie S.J. Tsai ${ }^{2}$ and H.M. Wong ${ }^{3}$ \\ ${ }^{I}$ Professor in Paediatric Dentistry, Faculty of Dentistry, The University of Hong Kong, Hong Kong SAR, China \\ ${ }^{2}$ Formerly postgraduate dental student in paediatric dentistry, Faculty of Dentistry, The University of Hong Kong, Hong \\ Kong SAR. Currently in private practice, China \\ ${ }^{3}$ Assistant Professor in Paediatric Dentistry, Faculty of Dentistry, The University of Hong Kong, China
}

\begin{abstract}
Aim: To investigate the prevalence of four major dental traits in the southern Chinese permanent dentition and to compare these with studies from different populations.

Materials and Methods: The material used in the study consisted of high quality study models collected from 725 randomly selected 12-year-old children in Hong Kong (358 males and 367 females). The various traits were assessed using standard diagnostic criteria. Literature and data related to dental traits in the permanent dentition were sourced using PubMed and hand searches.

Results: The mouth prevalence of shovelling, lingual tubercle, Carabelli's trait, and protostylid were $80.4 \%, 38.9 \%$, $50.5 \%$ and $37.5 \%$ respectively. The prevalence figure for the cusp type of Carabelli's trait in this study (23.7\%) was higher than for other Mongoloids. The prevalence figures for semi-shovel shaped maxillary incisors (42.6\% to 48.6\%) and the cusp type of protostylid trait in mandibular molars (10.1\%) were higher than for any other populations.
\end{abstract}

Conclusion: The higher prevalences of semi-shovel shaped maxillary incisors, and protostylid cusp on the mandibular molars can be considered to be characteristics of the southern Chinese permanent dentition.

Keywords: Dental traits, permanent dentition, southern Chinese.

\section{INTRODUCTION}

The term "trait" has been defined as a distinguishing feature, or characteristic of an individual. The frequency of occurrence of a trait may be low in a specific population because that trait is becoming progressively more, or less well developed in that population. Hence, it is not inconceivable that a trait could inadvertently be considered to be an anomaly, even though it may be a characteristic feature of that population. Thus, what may be considered to be an anomaly in one population may be a trait in another population. Furthermore, the dentition of man is changing in form, size and number. Studies have, according to Dahlberg [1], revealed that these changes are not taking place at the same rate in the various geographic and racial groups. This evolutionary tendency is probably the reason why there is so much variation in the number of cusps exhibited by the maxillary first primary molar of Japanese children [2].

The large variation in morphological features and their form may not be easily altered; thus, a trait of the human dentition can be a valuable diagnostic tool for anthropological studies in classifying and characterizing different ethnic

*Address correspondence to this author at the Paediatric Dentistry, Faculty of Dentistry, The University of Hong Kong, 2/F, Prince Philip Dental Hospital, 34 Hospital Road, Hong Kong SAR, China; Tel: +852 28590253; Fax: +852 25593803; E-mail: profnigelking@mac.com groups. From a skull that was found at Zhoukoudian upper cave in northern China which had shovel-shaped incisors, Weidenreich [3] concluded that there was a close link between the prehistoric homo-erectus and the modern Mongoloid populations; because shovelling of the incisors has always been associated with the Mongoloid samples such as Chinese and Japanese [4-6].

Investigations into racial differences in dental morphology have led to the hypothesis that the common origins of peoples are reflected to a certain degree in their similar phenotypic patterns. For example, studies of fossil material have show that the ancestors of all native Americans probably originated in northeast Asia [7]. The accumulation of data on the morphological traits of the teeth in different populations has led anthropologists to become more concerned with the evolutionary significance of these data, and to consider the mode of inheritance. The various morphological traits of the dentition are likely to be inherited; however, the mode of inheritance, of most traits, is at present poorly understood, and may well remain so for a long time.

Although teeth have proven to be an extremely valuable fossil material for scientists to study the history of man, unusual anomalous morphological features were mistakenly regarded by some early observers as aberrations and not considered to represent normal biological variation. One of the first traits to be recorded was Carabelli's trait in 1842 [8]. 
Shovelling of incisor teeth was first reported by Mühlreiter in 1870 (Mühlreiter 1870), while the number of cusps on maxillary molars was published in 1913 by Keith [9]. The cusps and grooves on mandibular molars were subsequently investigated by Gregory and Hellman in 1926 [10]. The twenty-eight observable dental traits that have been studied in the Mongoloid dentition include shovelling of the incisors teeth, Carabelli's trait, the number and form of cusps, ridges and fissure patterns, and three roots on the mandibular first molar [7, 11-13].

The southern Chinese are a specific group of Chinese who reside in the part of China that is south of the Yangtze river. Research works has indicated that there are differences in the peoples of northern and southern China. The southern Chinese are shorter than their northern Chinese counterparts, speak different dialects and have markedly different eating habits [14]. Since only limited data are available on the prevalence of the dental characteristics of the southern Chinese, there seems to be a need to investigate the major dental traits in this population. The aims of this study were to determine the prevalence of the various dental traits, such as shovelling, lingual tubercle, Carabelli's trait, and protostylid in the permanent dentition of twelve years old southern Chinese children in Hong Kong, and to determine if there were any inter-relationships between these major dental traits. By comparing these data with those on other populations, it was intended to determine if the permanent dentition of the southern Chinese has any features that may be considered to be characteristics of their dentition.

\section{MATERIALS AND METHODS}

The prevalence data of dental traits were based on plaster casts of the permanent dentition of 725 children (365 girls and 358 boys), which had been obtained from a randomly selected sample of 12 years old southern Chinese children in Hong Kong. Details of the sampling method were described in Part I of this series of papers.

In the study cast examination, individual teeth on the casts were examined by one calibrated examiner using an illuminated magnifying glass (x2) to diagnose the presence or, absence of a trait. Illustrated versions of the various classifications of the four traits, and a list of the teeth upon which they could be expected to occur, were prepared to enhance the accuracy of the diagnoses and to maintain the level of examiner reliability. The reasons for omitting some teeth from the investigation were: (i) poor quality or of the study cast; (ii) chipped or broken teeth; (iii) wear or attrition; (iv) gross caries; and (v) restorations. The following criteria were employed to diagnose the four dental traits.

\section{Shovelling}

An incisor or canine with an extraordinary development of the lateral borders and cingulum of the lingual surface of the crown, a depression in the central and incisal portions of the surface giving the impression of a shovel. Hrdlicka's classification [4] has four variations: (0) no shovel - no perceptible trace of rim and fossa or in which trace of these were so faint or imperfect as no to deserve special characterization; (1) trace of shovel - distinct traces of the enamel rim but which could not be classed yet as semi-shovel; (2) semi-shovel shaped - the enamel rim was distinct but the enclosed fossa was shallow; and (3) pronounced shovel shape - the enamel rim with the enclosed fossa were well developed.

\section{Lingual Tubercle}

A single or double protuberance arising from the cingulum of the lingual surface of the maxillary canine or incisor and extending less than half the distance from the cemento-enamel junction to the incisal edge. Lingual tubercle was classified as either present or absent. The type present was classified as either a single or double tubercle [15].

\section{Carabelli's Trait}

Either a tubercle of varying size, or a groove, or even a pit on the lingual surface of the protocone of the permanent maxillary first molar. The classification of Carabelli's trait was based upon Snyder's simplified index [16]; (0) no cusp and smooth - a completely smooth surface; (1) no cusp but small line - a surface having a furrow interrupting its continuity; (2) no cusp but pit - a surface having a pit interrupting its continuity; (3) cusp outline without apex - an eminence without a defining groove; (4) partial cusp without apex - a small cusp with a groove setting it off from the tooth surface; and (5) cusp with apex - a large cusp.

\section{Protostylid}

An additional cusp on the buccal surface of the mesiobuccal cusp of a mandibular molar. There were five subdivisions of the classification which was proposed by Snyder and his co-workers [16]; (0) no cusp - completely uninterrupted surface; 1) pit - a pit with a vertical wrinkle or irregular irregularities; (2) eminence - eminence of cusp without groove outline; (3) elevation - a small but positive elevation; (4) cusp - well defined cusp.

Reproducibility examinations were conducted to check the intra-examiner reliability. Approximately $10 \%$ of the 725 subjects were randomly chosen for re-examinations. In order to ensure that each trait was present in the reproducibility test, at least 5 subjects were chosen randomly who exhibited each of the traits. The Kappa coefficient $(\mathrm{K})$ was used to determine the intra-examiner reproducibility. To determine if there were any statistical differences between gender and side, the chi-square test was used to test the quantity of the proportions. To determine any association between the various traits, the Pearson correlation coefficients were used.

In order to be able to compare the prevalence data with those of other studies, literature and data from 1930 to 2009, which were related to dental traits in the permanent dentition, were sourced using PubMed and hand searches. The key words used for the PubMed searches were dental traits, permanent dentition, shovelling, lingual tubercle, Carabelli's trait, and protostylid. Reference lists of articles retrieved from the electronic database were then hand searched to identify additional articles that might provide information relevant to the objectives of this paper. It was impractical to perform a systemic review because the methodology used in the published studies varied, thus preventing valid statistical analyses.

\section{RESULTS}

The 725 subjects had a gender distribution of 358 males (49\%) and 367 females (51\%). The mean chronological ages 
were 12.5 years and 12.6 years for the males and females respectively. The intra-examiner reproducibility for the diagnosis of each the dental traits was calculated using Kappa coefficients; the values ranged from 0.44 (protostylid) to 0.66 (Carabelli's trait).

The mouth prevalence of the four major types of dental traits in the permanent dentition for southern Chinese boys and girls are shown in Table 1, while the tooth prevalences are displayed in Tables $\mathbf{2}$ to $\mathbf{5}$. Since there were no significant differences found between the genders, and between the left and right sides of the arch, the data were pooled for the determination of any associations between the four traits (Tables 6 and 7), and for comparison with those of other studies (Tables 8 to 12).

Shovelling, which was found on the incisors and canines had prevalence rates of $79.0 \%$ for the 367 girls and $81.6 \%$ for the 358 boys (Table 1). In almost $90 \%$ of those affected the shovelling occurred bilaterally. The semi-shovel type of shovelling was found to be the commonest type, with $45.6 \%$ of the incisors exhibiting this form. The tooth prevalence showed that the lateral incisors were the most frequently affected teeth (Table 2). The inter-relationship between shovelling and Carabelli's trait was found to be statistically significant in this study $(\mathrm{p}=0.021)$, see Table 7 . The semishovel type of shovelling was more prevalent in the southern Chinese $(42.6 \%$ to $68.0 \%)$ compared with other populations (up to $47.5 \%$ ), whereas the pronounced type of shovelling was more prevalent in other Mongoloids (Table 8).

Almost $40 \%$ of the children exhibited the lingual tubercle trait (Table 1). The single tubercle form was seen in $85 \%$ of the affected children. The tooth prevalence figures in Table 3 show that canines were more commonly affected than incisors. The inter-relationship between lingual tubercle and shovelling was found to be statistically significant in southern Chinese children $(\mathrm{p}=0.008)$, see Table 7 . The prevalence of lingual tubercle on canines in southern Chinese was comparable to that of other Mongoloids (Table 9).

Carabelli's trait which was found only on the permanent first molars affected $47.1 \%$ of the girls and $53.9 \%$ of the boys (Table 1). The line form (classification type 1) was the commonest type (Table 4). The inter-relationship between Carabelli's trait and lingual tubercle was found to be statisti-

Table 1. The Mouth Prevalence of the Various Dental Traits in the Permanent Dentition of 725 Twelve Years Old Southern Chinese Girls and Boys in Hong Kong

\begin{tabular}{|c|c|c|c|c|c|c|}
\hline \multirow{2}{*}{ Dental trait } & \multicolumn{2}{|c|}{ Girls $(N=367)$} & \multicolumn{2}{|c|}{ Boys $(N=358)$} & \multicolumn{2}{|c|}{ Total } \\
\hline & $\mathbf{n}$ & $\%$ & $\mathbf{n}$ & $\%$ & $\mathbf{n}$ & $\%$ \\
\hline Shovelling & 290 & 79.0 & 292 & 81.6 & 582 & 80.4 \\
\hline Lingual tubercle & 145 & 39.5 & 137 & 38.3 & 282 & 38.9 \\
\hline Carabelli's trait & 173 & 47.1 & 193 & 53.9 & 366 & 50.5 \\
\hline Protostylid & 144 & 39.2 & 128 & 35.8 & 272 & 37.5 \\
\hline
\end{tabular}

Table 2. The Prevalence of Shovelling for the Maxillary Permanent Anterior Teeth of 725 Twelve Years Old Southern Chinese Children in Hong Kong

\begin{tabular}{|c|c|c|c|c|}
\hline \multirow{2}{*}{ Tooth type } & \multirow{2}{*}{ Number of teeth examined } & \multicolumn{3}{|c|}{ Number and percentage of different types of shovelling trait } \\
\hline & & trace & semi-shovel & pronounced shovel \\
\hline 11 & 722 & $\begin{array}{c}168 \\
(23.3 \%)\end{array}$ & $\begin{array}{c}348 \\
(48.2 \%)\end{array}$ & $\begin{array}{c}56 \\
(7.8 \%)\end{array}$ \\
\hline 12 & 721 & $\begin{array}{c}102 \\
(14.2 \%)\end{array}$ & $\begin{array}{c}307 \\
(42.6 \%)\end{array}$ & $\begin{array}{c}153 \\
(21.2 \%)\end{array}$ \\
\hline 13 & 701 & $\begin{array}{c}154 \\
(22.0 \%)\end{array}$ & $\begin{array}{c}105 \\
(15.0 \%)\end{array}$ & $\begin{array}{c}26 \\
(3.7 \%)\end{array}$ \\
\hline 21 & 720 & $\begin{array}{c}169 \\
(23.5 \%)\end{array}$ & $\begin{array}{c}350 \\
(48.6 \%)\end{array}$ & $\begin{array}{c}54 \\
(7.5 \%)\end{array}$ \\
\hline 22 & 721 & $\begin{array}{c}111 \\
(15.4 \%)\end{array}$ & $\begin{array}{c}303 \\
(42.0 \%)\end{array}$ & $\begin{array}{c}147 \\
(20.4 \%)\end{array}$ \\
\hline 23 & 703 & $\begin{array}{c}157 \\
(22.3 \%)\end{array}$ & $\begin{array}{c}102 \\
(14.5 \%)\end{array}$ & $\begin{array}{c}23 \\
(3.3 \%)\end{array}$ \\
\hline
\end{tabular}


Table 3. The Prevalence of Lingual Tubercle for the Maxillary Permanent Anterior Teeth of 725 Twelve Years Old Southern Chinese Children in Hong Kong

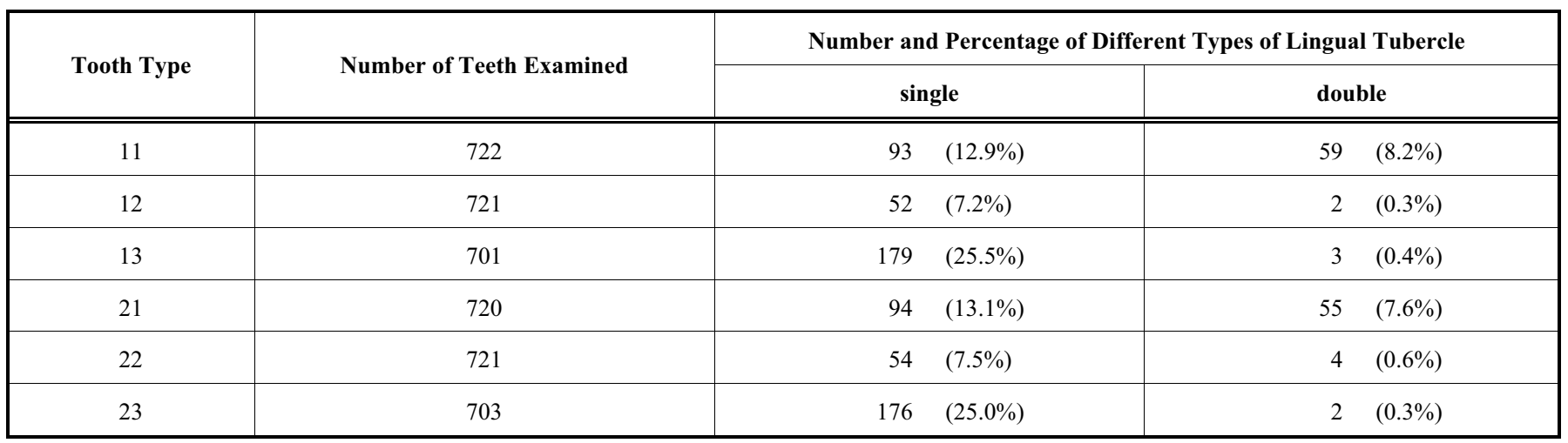

Table 4. The Prevalence of Carabelli's Trait for the Maxillary First Permanent Molars of 725 Twelve Years Old Southern Chinese Children in Hong Kong

\begin{tabular}{|c|c|c|c|c|c|c|}
\hline \multirow{2}{*}{ Tooth Type } & \multirow{2}{*}{$\begin{array}{c}\text { Number of Teeth } \\
\text { Examined }\end{array}$} & \multicolumn{5}{|c|}{ Number and Percentage of Different Types of Carabelli's Trait } \\
\hline & & line & pit & cusp outline & partial cusp & cusp with apex \\
\hline 16 & 720 & $\begin{array}{c}137 \\
(19.0 \%)\end{array}$ & $\begin{array}{c}31 \\
(4.3 \%)\end{array}$ & $\begin{array}{c}103 \\
(14.3 \%)\end{array}$ & $\begin{array}{c}27 \\
(3.8 \%)\end{array}$ & $\begin{array}{c}40 \\
(5.6 \%)\end{array}$ \\
\hline 26 & 723 & $\begin{array}{c}111 \\
(15.4 \%)\end{array}$ & $\begin{array}{c}30 \\
(4.2 \%)\end{array}$ & $\begin{array}{c}102 \\
(14.1 \%)\end{array}$ & $\begin{array}{c}27 \\
(3.7 \%)\end{array}$ & $\begin{array}{c}38 \\
(5.3 \%)\end{array}$ \\
\hline
\end{tabular}

Table 5. The Prevalence of Protostylid for the First and Second Mandibular Permanent Molars of 725 Twelve Years Old Southern Chinese Children in Hong Kong

\begin{tabular}{|c|c|c|c|c|c|}
\hline Tooth Type & Number of Teeth Examined & \multicolumn{4}{|c|}{ Number and Percentage of Different Types of Protostylid } \\
\hline 46 & 715 & $\begin{array}{c}146 \\
(20.4 \%)\end{array}$ & $\begin{array}{c}33 \\
(4.6 \%)\end{array}$ & $\begin{array}{c}23 \\
(3.2 \%)\end{array}$ & $\begin{array}{c}16 \\
(2.2 \%)\end{array}$ \\
\hline 36 & 708 & $\begin{array}{c}153 \\
(21.6 \%)\end{array}$ & $\begin{array}{c}33 \\
(4.7 \%)\end{array}$ & $\begin{array}{c}20 \\
(2.8 \%)\end{array}$ & $\begin{array}{c}15 \\
(2.1 \%)\end{array}$ \\
\hline 37 & 571 & $\begin{array}{c}30 \\
(5.3 \%)\end{array}$ & $\begin{array}{c}7 \\
(1.2 \%)\end{array}$ & $\begin{array}{c}2 \\
(0.4 \%)\end{array}$ & $\begin{array}{c}2 \\
(0.4 \%)\end{array}$ \\
\hline
\end{tabular}

Table 6. The Number and Percentage of 725 Twelve Years Old Southern Chinese Children in Hong Kong with Teeth Affected by Combinations of Traits

\begin{tabular}{|c|c|c|}
\hline Combinations of Traits & $\mathbf{n}$ & \% \\
\hline \hline Carabelli's trait + Protostylid & 163 & 22.5 \\
\hline Carabelli's trait + Shovelling & 306 & 42.2 \\
\hline Carabelli's trait + Lingual tubercle & 172 & 23.7 \\
\hline Shovelling + Lingual tubercle & 271 & 37.4 \\
\hline Shovelling + Protostylid & 226 & 31.2 \\
\hline Protostylid + Lingual tubercle & 98 & 13.5 \\
\hline
\end{tabular}


Table 7. The Inter-Relationships (Correlation Coefficients) Between Shovelling, Lingual Tubercle, Carabelli's Trait and Protostylid in 725 Twelve Years Old Southern Chinese Children in Hong Kong

\begin{tabular}{|c|c|c|c|}
\hline & Lingual tubercle & Carabelli's trait & Protostylid \\
\hline \hline Shovelling & 0.33 & 0.19 & 0.03 \\
& $* *$ & $*$ & 0.01 \\
\hline Lingual tubercle & & $* * 27$ & $\mathrm{~ns}$ \\
& & & 0.31 \\
\hline
\end{tabular}

$* * 0.01<\mathrm{p}<0.05$.

$* * 0.001<\mathrm{p}<0.01$

ns - not significant.

Table 8. The Prevalence, Expressed as a Percentage, for the Shovelling Trait on the Permanent Maxillary Incisors in Published Studies

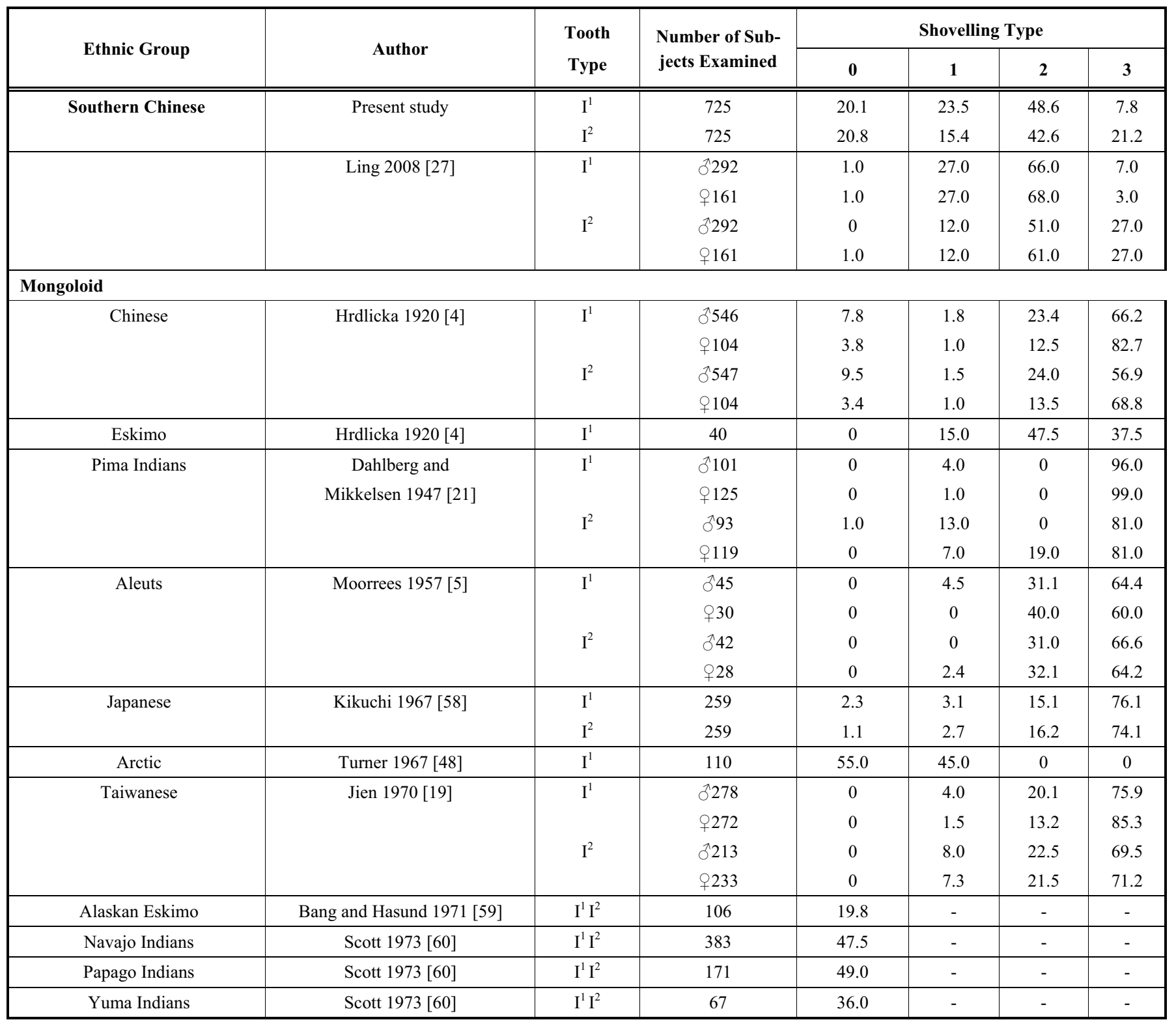


(Table 8). Contd.....

\begin{tabular}{|c|c|c|c|c|c|c|c|}
\hline \multirow{2}{*}{ Ethnic group } & \multirow{2}{*}{ Author } & \multirow{2}{*}{$\begin{array}{l}\text { Tooth } \\
\text { type }\end{array}$} & \multirow{2}{*}{$\begin{array}{l}\text { Number of sub- } \\
\text { jects examined }\end{array}$} & \multicolumn{4}{|c|}{ Shovelling type } \\
\hline & & & & 0 & 1 & 2 & 3 \\
\hline Mohave Indians & Scott $1973[60]$ & $\mathrm{I}^{1} \mathrm{I}^{2}$ & 48 & 34.5 & - & - & - \\
\hline $\begin{array}{c}\text { Lengua Indians in } \\
\text { Paraguay }\end{array}$ & Kieser and Preston 1981 [61] & $\mathrm{I}^{1} \mathrm{I}^{2}$ & 202 & 4.5 & - & - & - \\
\hline Pima Indians & Scott et al 1983 [23] & $\begin{array}{l}\mathrm{I}^{1} \\
\mathrm{I}^{2}\end{array}$ & $\begin{array}{l}1595 \\
+659 \\
\bigcirc 514 \\
+563 \\
\end{array}$ & $\begin{array}{c}0 \\
0 \\
0 \\
0.2 \\
\end{array}$ & $\begin{array}{l}23.2 \\
18.8 \\
58.4 \\
52.4 \\
\end{array}$ & $\begin{array}{l}39.9 \\
42.9 \\
27.2 \\
30.9 \\
\end{array}$ & $\begin{array}{l}37.5 \\
38.3 \\
14.4 \\
16.6 \\
\end{array}$ \\
\hline \multicolumn{8}{|l|}{ Caucasian } \\
\hline American whites & Hrdlicka 1920 [4] & $\begin{array}{l}\mathrm{I}^{1} \\
\mathrm{I}^{2}\end{array}$ & $\begin{array}{l}2000 \\
2000 \\
\end{array}$ & $\begin{array}{l}68.4 \\
54.8 \\
\end{array}$ & $\begin{array}{l}23.2 \\
23.2 \\
\end{array}$ & $\begin{array}{l}6.4 \\
8.1 \\
\end{array}$ & $\begin{array}{l}2.0 \\
1.2 \\
\end{array}$ \\
\hline Finns & $\begin{array}{c}\text { Koski and Hantala } \\
1952[62]\end{array}$ & $\begin{array}{l}\mathrm{I}^{1} \\
\mathrm{I}^{2}\end{array}$ & $\begin{array}{l}423 \\
408 \\
\end{array}$ & $\begin{array}{l}9.0 \\
7.1 \\
\end{array}$ & $\begin{array}{l}76.4 \\
73.4 \\
\end{array}$ & $\begin{array}{l}10.9 \\
16.7\end{array}$ & $\begin{array}{l}3.8 \\
2.9\end{array}$ \\
\hline $\begin{array}{c}\text { Southeastern } \\
\text { British }\end{array}$ & Berry 1976 [24] & $\begin{array}{l}\mathrm{I}^{1} \\
\mathrm{I}^{2} \\
\end{array}$ & $\begin{array}{l}218 \\
210\end{array}$ & $\begin{array}{l}90.6 \\
92.9 \\
\end{array}$ & - & - & $\begin{array}{l}- \\
- \\
\end{array}$ \\
\hline $\begin{array}{c}\text { Northwestern } \\
\text { British } \\
\end{array}$ & Berry 1976 [24] & $\begin{array}{l}\mathrm{I}^{1} \\
\mathrm{I}^{2} \\
\end{array}$ & $\begin{array}{l}218 \\
226 \\
\end{array}$ & $\begin{array}{l}79.4 \\
84.5 \\
\end{array}$ & - & - & $\begin{array}{l}- \\
- \\
\end{array}$ \\
\hline Orkney Islanders & Berry 1976 [24] & $\begin{array}{l}\mathrm{I}^{1} \\
\mathrm{I}^{2}\end{array}$ & $\begin{array}{l}201 \\
143 \\
\end{array}$ & $\begin{array}{l}91.3 \\
82.9 \\
\end{array}$ & - & - & - \\
\hline Shetland Islanders & Berry 1976 [24] & $\begin{array}{l}\mathrm{I}^{1} \\
\mathrm{I}^{2}\end{array}$ & $\begin{array}{l}185 \\
123 \\
\end{array}$ & $\begin{array}{l}88.1 \\
74.8 \\
\end{array}$ & - & - & - \\
\hline Bonn Germans & Berry $1976[24]$ & $\begin{array}{l}\mathrm{I}^{1} \\
\mathrm{I}^{2}\end{array}$ & $\begin{array}{l}182 \\
152 \\
\end{array}$ & $\begin{array}{l}47.0 \\
55.3 \\
\end{array}$ & - & - & - \\
\hline $\begin{array}{c}\text { Heidelberg } \\
\text { Germans }\end{array}$ & Berry 1976 [24] & $\begin{array}{l}\mathrm{I}^{1} \\
\mathrm{I}^{2} \\
\end{array}$ & $\begin{array}{l}112 \\
100 \\
\end{array}$ & $\begin{array}{l}53.1 \\
57.5 \\
\end{array}$ & - & - & $\begin{array}{l}- \\
- \\
\end{array}$ \\
\hline Jats Indians & $\begin{array}{c}\text { Kaul and Prakash } \\
1981[63]\end{array}$ & $\begin{array}{l}\mathrm{I}^{1} \\
\mathrm{I}^{2}\end{array}$ & $\begin{array}{l}\jmath^{\top} 283 \\
+231 \\
\overbrace{}^{\top} 251 \\
+202 \\
\end{array}$ & $\begin{array}{c}18.0 \\
6.9 \\
29.1 \\
19.2 \\
\end{array}$ & $\begin{array}{l}36.8 \\
24.7 \\
29.7 \\
40.9 \\
\end{array}$ & $\begin{array}{l}26.5 \\
46.8 \\
23.1 \\
23.7 \\
\end{array}$ & $\begin{array}{l}18.7 \\
21.4 \\
19.1 \\
16.3 \\
\end{array}$ \\
\hline Canadian whites & $\begin{array}{c}\text { Saunders and } \\
\text { Mayhall } 1982[64]\end{array}$ & $\begin{array}{l}\mathrm{I}^{1} \\
\mathrm{I}^{2}\end{array}$ & $\begin{array}{l}827 \\
827 \\
\end{array}$ & $\begin{array}{l}77.1 \\
78.9 \\
\end{array}$ & $\begin{array}{l}19.4 \\
18.3 \\
\end{array}$ & $\begin{array}{l}3.0 \\
2.3 \\
\end{array}$ & $\begin{array}{l}0.5 \\
0.5 \\
\end{array}$ \\
\hline American whites & Hsu et al. 1997 [65] & $\mathrm{I}^{1}$ & 142 & 31.7 & - & - & - \\
\hline American whites & $\begin{array}{c}\text { Edgar and Lease } \\
2007[66]\end{array}$ & $\begin{array}{l}\mathrm{I}^{1} \\
\mathrm{I}^{2}\end{array}$ & $\begin{array}{l}53 \\
52 \\
\end{array}$ & $\begin{array}{l}25.0 \\
37.0\end{array}$ & $\begin{array}{l}53.0 \\
48.0\end{array}$ & $\begin{array}{l}21.0 \\
15.0\end{array}$ & $\begin{array}{c}2.0 \\
0\end{array}$ \\
\hline Jordanians & Khraisat et al. 2007 [46] & $\mathrm{I}^{1} \mathrm{I}^{2}$ & 300 & 47.0 & - & - & - \\
\hline Negroid & & & & & & & \\
\hline $\begin{array}{c}\text { Sub-Saharan } \\
\text { Africans }\end{array}$ & Irish 1997 [25] & $\mathrm{I}^{1}$ & 976 & 94.7 & - & - & - \\
\hline Others & & & & & & & \\
\hline Queckchi Indians & Escobar et al. 1977 [67] & $\mathrm{I}^{1}$ & 540 & 51.5 & - & - & - \\
\hline $\begin{array}{c}\text { Taiwan aborigines } \\
\text { (Ami) }\end{array}$ & Liu 1977 [68] & $\mathrm{I}^{2}$ & 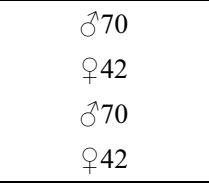 & $\begin{array}{r}2.5 \\
2.4 \\
3.5 \\
11.3 \\
\end{array}$ & $\begin{array}{c}25.9 \\
7.3 \\
14.7 \\
11.3 \\
\end{array}$ & $\begin{array}{c}14.2 \\
19.5 \\
20.8 \\
8.5 \\
\end{array}$ & $\begin{array}{l}57.3 \\
70.7 \\
61.0 \\
69.0 \\
\end{array}$ \\
\hline $\begin{array}{c}\text { Taiwan aborigines } \\
\text { (Atayal) }\end{array}$ & Liu $1977[68]$ & $\begin{array}{l}\mathrm{I}^{1} \\
\mathrm{I}^{2}\end{array}$ & $\begin{array}{l}781 \\
\not 49 \\
\precsim 81 \\
+49\end{array}$ & $\begin{array}{c}2.1 \\
1.2 \\
10.5 \\
11.9\end{array}$ & $\begin{array}{c}2.1 \\
4.8 \\
0 \\
2.3\end{array}$ & $\begin{array}{c}22.3 \\
14.3 \\
11.6 \\
4.8\end{array}$ & $\begin{array}{l}73.4 \\
79.8 \\
77.9 \\
80.9\end{array}$ \\
\hline
\end{tabular}

${ }^{0}=$ no shovel, ${ }^{1}=$ trace of shovel, ${ }^{2}=$ semi-shovel shaped, ${ }^{3}=$ pronounced shovel shape. 
Table 9. The Prevalence, Expressed as a Percentage, of the Lingual Tubercle Trait on the Permanent Maxillary Incisors and Canines in Published Studies

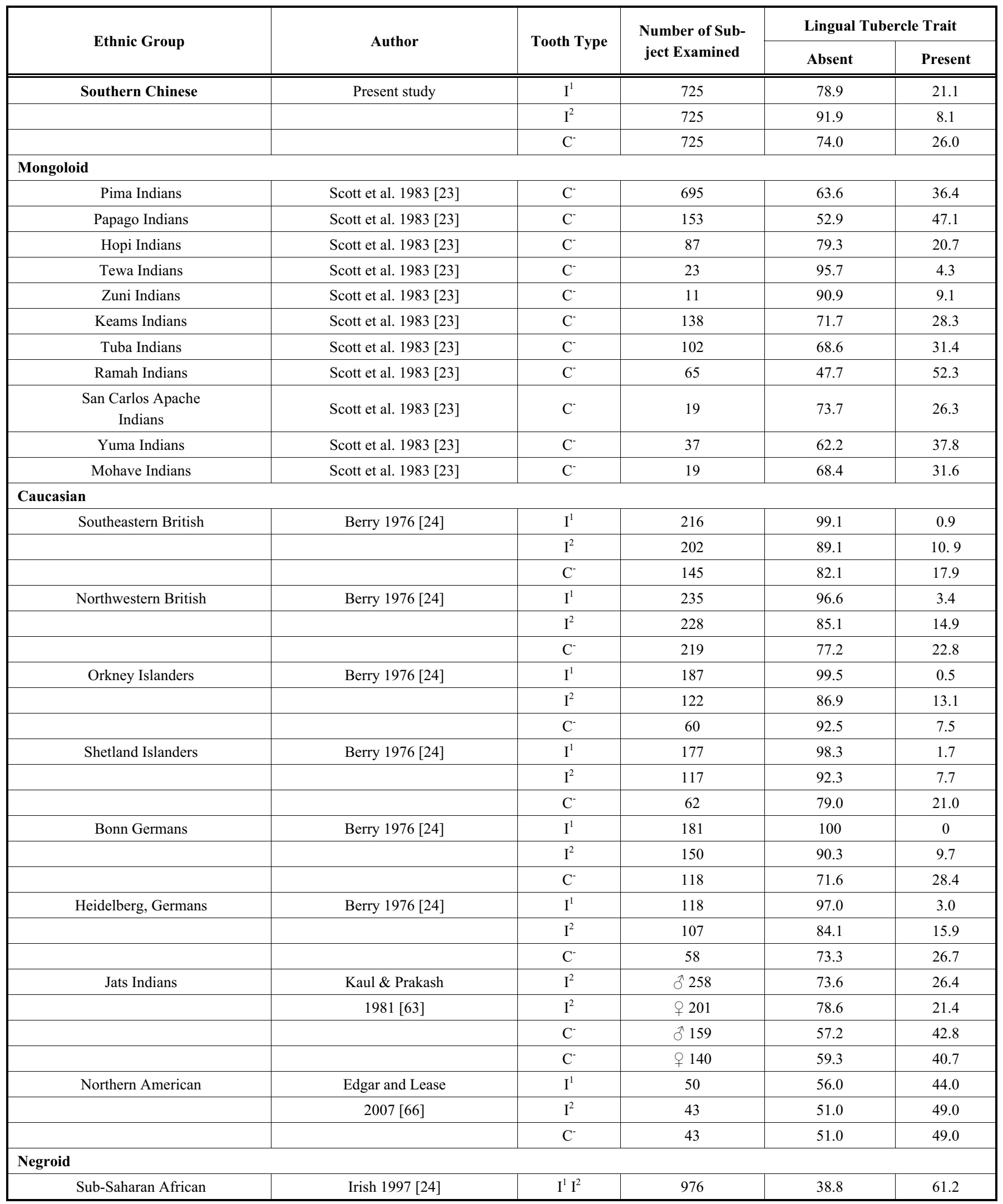


Table 10. The Prevalence, Expressed as a Percentage, for Carabelli's Trait on the Permanent Maxillary First Molars in Published Studies

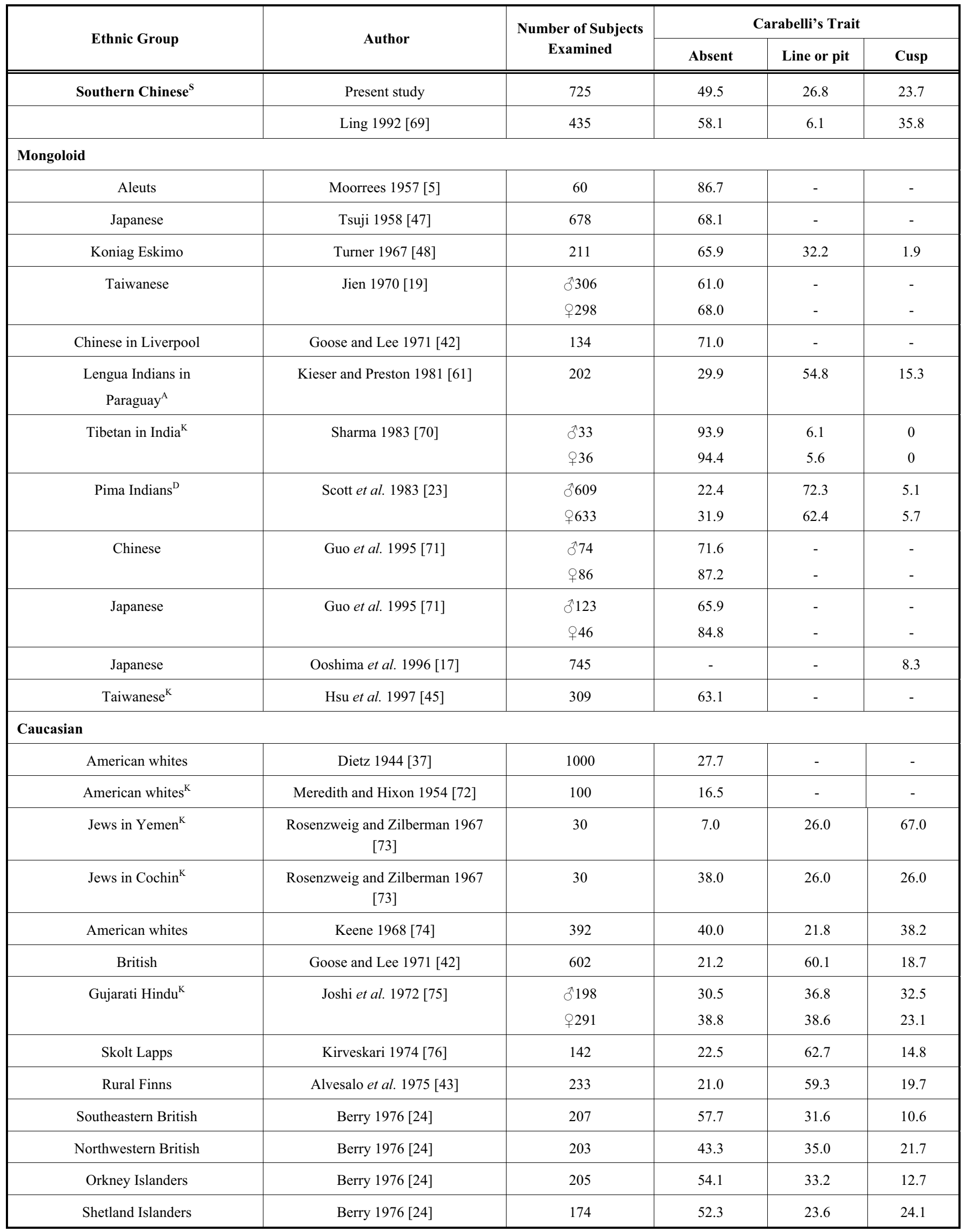


(Table 10). Contd.....

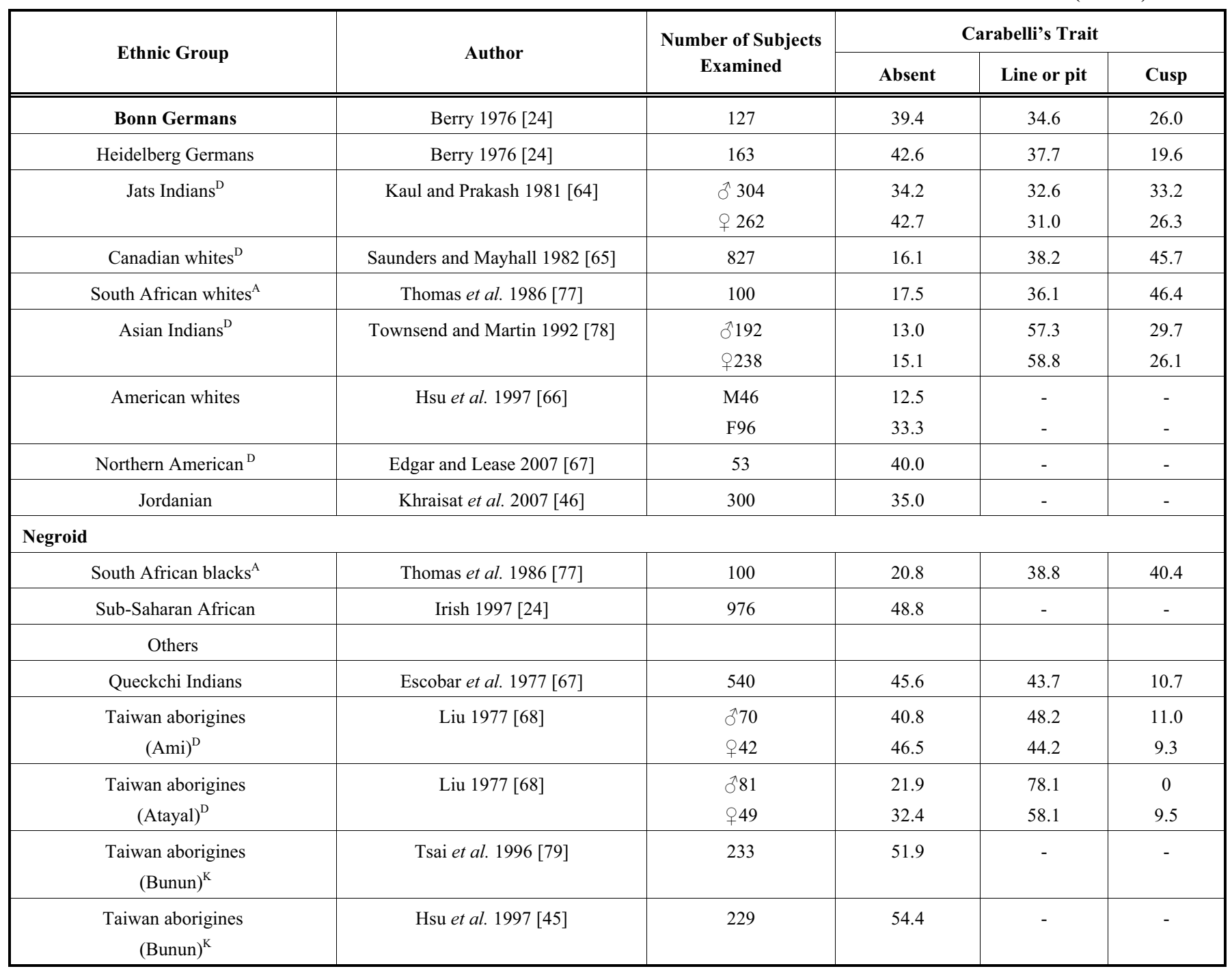

${ }^{\text {A}}$ Alvesalo's index (Alvesalo et al. 1975) was used in the study. The original data were reanalysed for comparison $(\mathrm{Absent}=0, \mathrm{Line}$ or pit $=1+2$, Cusp $=3+4)$.

Dahlberg's index (Dahlberg 1963) was used in the study. The original data were reanalysed for comparison $(\mathrm{Absent}=0, \mathrm{Line}$ or pit $=1+2+3+4, \mathrm{Cusp}=5+6+7)$.

${ }^{K}$ Kraus's index (Kraus 1951) was used in the study. The original data were reanalysed for comparison (Absent $=a$, Line or pit $=b$, Cusp $=\mathrm{c}$ ).

${ }^{\mathrm{s}}$ Snyder's simplified index (Snyder et al. 1969) was used in the study. The original data were reanalysed for comparison $(\mathrm{Absent}=0, \mathrm{Line}$ or pit $=1+2, \mathrm{Cusp}=3+4+5)$.

cally significant in this study $(p=0.004)$, see Table 7 . The prevalence of Carabelli's trait for southern Chinese is comparable with the prevalence for some Caucasian groups. Moreover, the prevalence of Carabelli's cusp in southern Chinese, at between $23.7 \%$ and $35.8 \%$, was highest among the Mongoloids (Tables 10 and 12).

There were $37.5 \%$ children that were affected by protostylid (Table 1). The buccal pit form is the most commonly seen type (Table 5). The inter-relationship between Carabelli's trait and protostylid was found to be statistically significant in southern Chinese children $(p=0.005)$, see Table 7. The prevalence of cusp type of protostylid in this study $(10.1 \%)$ was higher than for the other ethnic groups (Table 11).

\section{DISCUSSION}

The studying of traits on dental casts is comparable to using fossilized material to diagnose characteristics of the dentition of pre-historic man. Detailed information can usually be successfully obtained from these sources. This may indeed be more reliable than direct clinical examinations for which instant clinical decisions have to be made and visual access is restricted in the oral cavity [17]. Use of an oral examination may result in information being inadvertently not collected. For example, the line form of Carabelli's trait cannot be easily detected in the clinical environment because the quality and direction of the light can be critical factor. Similarly, a double lingual tubercle of a central or lateral incisor can be very difficult to detect clinically, unless magnifying glasses are used, which is easier to do on a cast than in the mouth. Thus, the studying of dental casts was considered to be superior to the clinical method of examination. However, it is essential that the dental casts are a true and accurate reproduction of the original teeth and that they have not been damaged during preparation or storage.

Diagnostic criteria for the four dental traits were difficult to develop even with the aid of previously published literature because there is not a lack of universally accepted classifications for each trait. So, the different diagnostic criteria used in this study, and those used in the various published 
Table 11. The Prevalence, Expressed as a Percentage, for the Protostylid Trait on the Permanent Mandibular Molars in Published Studies

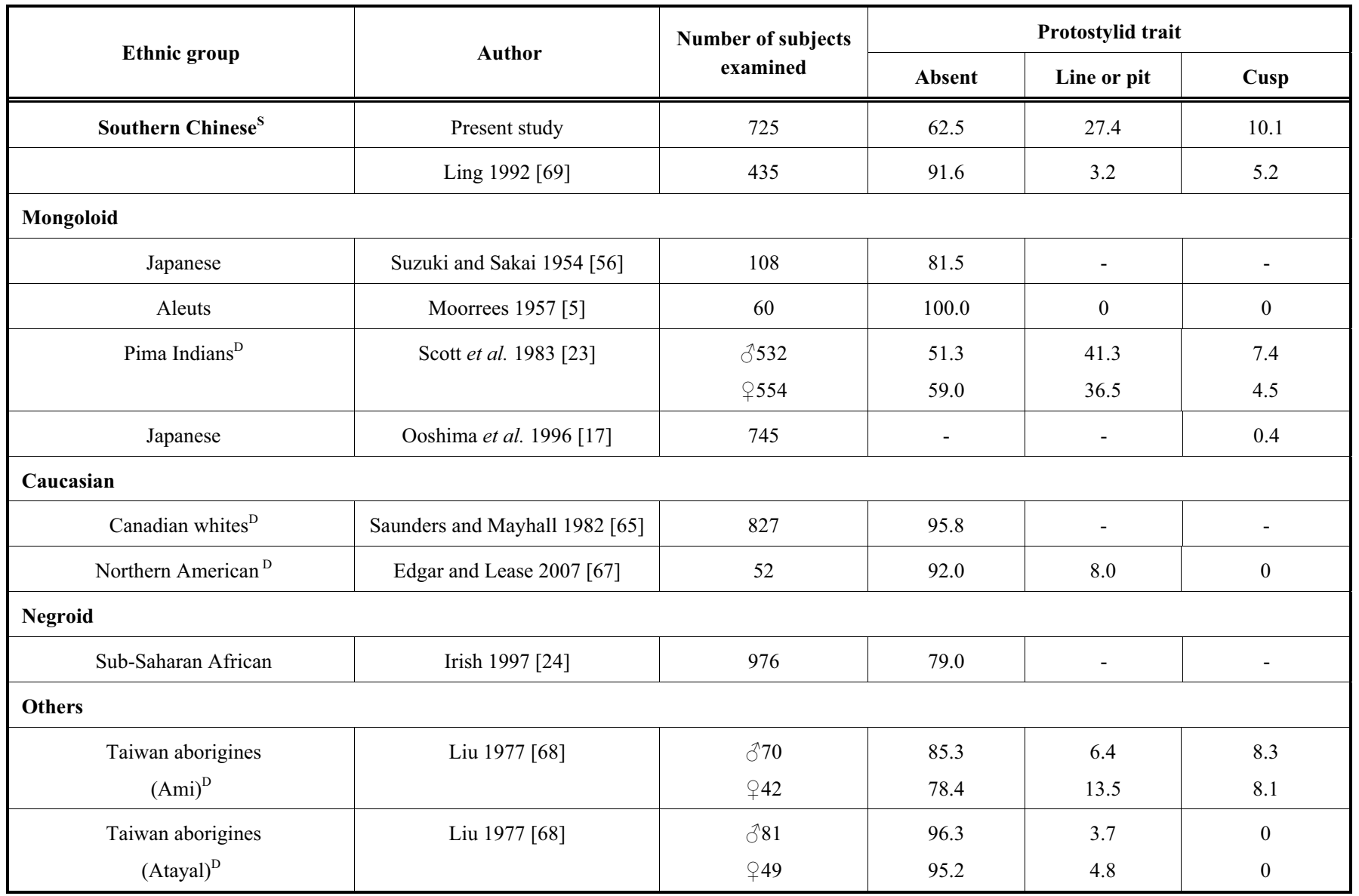

Dahlberg's index (Dahlberg 1963) was used in the study. The original data were reanalysed for comparison $($ Absent $=0, \mathrm{Line}$ or pit $=1+2, \mathrm{Cusp}=3+4+5+6+7)$.

${ }^{\text {s}}$ Snyder's index (Snyder et al. 1969$)$ was used in the study. The original data were reanalysed for comparison $($ Absent $=0$, Line or pit $=1$, Cusp $=2+3+4)$.

Table 12. The Frequency of Various Traits in the Permanent Dentition of Southern Chinese People, other Mongoloid Groups and Caucasians

\begin{tabular}{|c|c|c|c|}
\hline Dental Trait & Southern Chinese & Mongoloid (not southern Chinese) & Caucasian \\
\hline \hline Shovelling trait & high & low to moderate & varied \\
\hline Lingual tubercle trait & low & varied & moderate to high \\
\hline Carabelli's trait & moderate & low & varied \\
\hline Carabelli's cusp & low to moderate & low & low \\
\hline Protostylid trait & low to moderate & low & \\
\hline Protostylid cusp & & & low \\
\hline
\end{tabular}

Chance of occurrence:

low: $\quad<30 \%$

moderate $\quad 30 \%-60 \%$

high: $\quad>60 \%$

studies may be one of the reasons why there is some variation in the results that have been published. Comparability is further worsened by investigators not studying the same teeth; most of the investigations of shovelling omitted to look at the maxillary canines and the mandibular incisors.

Even though the age of the subjects was selected to provide the maximum number of teeth in the best condition, there may have been some loss of potential data. For instance, the maxillary canines were not always fully erupted, especially in the males. The additional information that could have been gained from the canines could have slightly increased the prevalence of the shovelling and lingual tubercle traits. The same issues may be applicable to the second molars in respect of the protostylid trait. 
The four major traits will be discussed respectively by first considering the physical characteristic, followed by the prevalence of that trait in the permanent dentition. The objective is to demonstrate any similarities or differences between the Mongoloid and Caucasoid dentitions, and where data are available to identify any distinctive features in the data for the permanent dentition of the southern Chinese.

\section{Shovelling}

The resemblance of an incisor to a shovel results from the combination of a concave lingual surface with elevated marginal ridges [4]. The maxillary as well as the mandibular anterior teeth can be found to have marginal ridges [4]. However, the more exaggerated forms of shovelling are usually exhibited by the maxillary rather than mandibular incisor teeth. Furthermore, the trait is more common in permanent than primary incisor teeth $[4,18]$. Although females were affected more than males in one study, the differences were not statistically significant [19], so gender variation is unlikely.

Most studies have adapted the classification proposed by Hrdlicka which recognised four degrees of shoveling; which are pronounced shovelling, "semi" shovelling and the trace type of shovelling [4]. However, the diagnostic criteria in different studies have not always been consistent. There may be errors in the classification of the shovel-shaped central and lateral incisors because the lateral incisor has a smaller mesio-distal dimension and, consequently, the same depth in the shovel may be classified as a higher degree of shovelshape $[6,20]$. Therefore, Carbonell [6] added a quantitative measuring device to classify the different degrees of shovelling. Using this device, a measurement of $+1 \mathrm{~mm}$ was considered to indicate shovel, $1 \mathrm{~mm}$ semi-shovel, and $-1 \mathrm{~mm}$ a trace.

Since Hrdlicka's report of this anomaly in 1920, shovelling has been accepted as a trait of the Mongoloid dentition. High prevalences have been reported in Eskimos [4], Pima Indians [21-23], north American Indians [4], and Aleuts [5]. The reverse has been found for Europeans [24] and Negroids [25]. Negroids have had almost no intermixing with Chinese, and they have an extremely low prevalence of shovelling, while in Hawaii, where Europeans have mixed with Polynesian, Melanesian and Chinese, the prevalence is intermediate. Therefore, it has been hypothesised that China was the source of this trait, so that when a population is geographically further removed from China, it demonstrates a lower frequency of shovelling [1]. Furthermore, environmental factors do not appear to play a role in the expression of this trait because it was found that Chinese born in China and the United States of America had similar prevalence of the trait [26]. Thus, it is quite accurate to describe shovelling as a characteristic for populations of Mongoloids, irrespective of the geographic region.

As expected, most of the maxillary incisors examined in this study were found to demonstrate shovelling, giving this trait a prevalence comparable to that of other Mongoloid groups and making it much higher than reported for Caucasians and Negroids. But what is interesting is that not all of the children in this study were affected to the same degree by this trait, when compared with other Chinese groups [4, 19, 27]. This could indicate that the trait has an autosomal reces- sive mode of inheritance, or that it is autosomal dominant but with variable expressivity. Alternatively, it could be that the southern Chinese are composed of different subgroups whose ancestors did not exhibit this trait. Study of fossil material of different racial groups from different historical periods could provide more information about this dilemma.

The frequency distributions of the semi-shovel shaped incisors were very high in southern Chinese, $48.6 \%$ in central incisors and $42.6 \%$ in lateral incisors (Table 8). However, the lower prevalence of pronounced shovel shaped incisors was noted as compared with other Mongoloids, and even with other Chinese populations studied by Hrdlicka [4] and Jien [19]. The degree of shovelling has been used to differentiate ethnically between the Pueblo Indians and the Plains Indians [28], and some Asian and African populations [29]. Unfortunately, the proportions of the subjects who were of northern Chinese origin were not stated clearly in Hrdlicka's and Jien's studies. Further studies of the northern Chinese is required to differentiate between the sub-groups of the Chinese population.

\section{Lingual Tubercle}

Lingual tubercle is a rounded elevation on the lingualgingival ridge of an anterior tooth. Because the tubercle has been more frequently observed and is better developed in fossil than in modern man, it is believed to be a derivative of the cingulum and a feature of evolution of the primate [3]. It may be long and narrow, or short and stumpy. It may be single, double, or multiple [30]. When double or multiple tubercles are present, the distal one is usually larger than the mesial one [30]. It has been reported that the tubercle is always present as two short projections on either side of the lingual ridge and that the mandibular canine almost never exhibits a lingual tubercle [31]. Berry [32] showed a significant correlation of lingual tubercle with Carabelli's trait. Similarly, lingual tubercle was found in this study to be closely related to Carabelli's trait, and additionally to the shovelling trait (Table 7).

There was a high prevalence of lingual tubercle on the permanent anterior teeth in southern Chinese at $38.9 \%$ (Table 1), which is similar to that which occurred in the primary dentition (43.5\%), see Part IV of this paper series. Lingual tubercle occurred most frequently on the canines and to a lesser extend on the maxillary incisors in southern Chinese; similar results have also been reported for Caucasians (Table 9). Since the prevalence figures for other Mongoloids were only on canines, further comparisons are impossible to make. However, the prevalence of lingual tubercle on canines in southern Chinese was comparable to those of other Mongoloids (Table 9). In this study, the single lingual tubercle affected the teeth more than the double tubercle variation (Table 3). Nevertheless, the prevalence figures of different types of lingual tubercle were not reported for the majority of other studies.

\section{Carabelli's Trait}

Carabelli's trait is expressed as either a tubercule of varying size, or a groove, or even a pit on the lingual surface of the protocone of the primary maxillary second molar, or the permanent maxillary first molar. The name has been credited to von Carabelli, who first described this feature in 1842 in a 
paper by Korenhof [33]. It has also been referred to as the tuberculum anomalies, tuberculum Carabelli and tuberculum imparon. Although some specimens of Paleolithic man have been found to exhibit Carabelli's trait on the maxillary molars [34], this has not been a consistence finding, and it is a generally held opinion that the cusp form of the Carabelli trait is a recent acquisition of man. Conversely, the pit form of the Carabelli trait has been observed in numerous specimens of Neanderthal man and has been considered to be a consistent characteristic of the maxillary molars [35]. Examples of the Australopithecinas and Dryopithecus rhenanus also displayed the Carabelli pit $[35,36]$. Thus, it is reasonable to conclude that the Carabelli trait is significant in the evolution of man and possibly in different racial groups.

The Carabelli trait is said to be an inherited characteristic [37]. Data from studies of twins support this aetiological hypothesis. However, although an autosomal dominant mode of inheritance has been proposed, the degree of expression of the trait in twins has varied from fully concordant to fully discordant [38]. Thus, because of the varying manifestations and prevalence of Carabelli's trait the mode of inheritance is probably not a simple Mendelian pattern. A high degree of equivalence of Carabelli trait expression between primary and permanent molars was demonstrated by Kieser [39]. It was then hypothesized that the high degree of withinindividual equivalence suggests a low epigenetic and high genetic influence on Carabelli trait expression and that the findings support the clonal rather than the field theory of tooth morphogenesis [39].

No dental variable has stimulated more attempts at classification than Carabelli's trait. Unfortunately, this makes the various standards unduly complicated. In the early literature, manifestations below the level of distinct tubercle were not often counted [40]. From the 1940s on, research workers started taking the full Carabelli continuum into account, and classifications included four to ten grades of expression of the trait [41-43]. For example, eight classes of expression were reported by Dahlberg [44] and six by Snyder and colleagues [16]. Thus, caution should be exercised when comparing the prevalence figures from different studies to ensure that similar features of the Carabelli's trait are being compared.

The statistically significant inter-relationship between Carabelli's trait and shoveling was demonstrated by other investigators $[45,46]$ and it was supported by the present work (Table 7). The prevalence of Carabelli's trait has been reported to be higher in males than in females in the permanent dentition [42, 47-50]. However, gender difference was not found in this study (Table 1). Interestingly, significant differences were observed in the occurrence of Carabelli's trait between the upper and lower income groups for the primary dentition, and between the upper and middle income groups for the permanent dentition in a study conducted in south India [49].

It was reported by some researchers that children with Carabelli's cusp tend to have teeth with crown that have a larger bucco-lingual dimension [51-52]. Kondo and Townsend [52] postulated that larger molar crowns in individuals with the genotype for Carabelli trait expression, are more likely to display Carabelli cusps, whereas their teeth with smaller crowns are more likely to display reduced forms of the trait. Moreover, the pattern of folding of the internal enamel epithelium in developing molar crowns, particularly in the protocone region, can be modified by a developing Carabelli cusp [52].

Prevalence data for the primary dentition for all degrees of Carabelli's trait indicate that it is more common in Caucasian children than Mongoloid children (Part IV of this paper series). For the permanent dentition, Carabelli's trait appears to be generally commonest among European populations, followed by African populations, and American Indians, with the lowest prevalence occurring in the other Mongoloid races (Table 10). However, the prevalences of $41.9 \%$ to $50.5 \%$ for southern Chinese are comparable to the prevalence for some Caucasian groups (Table 10). The general trend is for this trait to be more common in southern Chinese than other Mongoloid groups. When only the tubercle and cusp forms are considered, the pattern of geographic variation in Carabelli's trait is not particularly striking [40]. Moreover, the prevalence of Carabelli's cusp in southern Chinese, of between $23.7 \%$ and $35.8 \%$, was the highest among the Mongoloids (Table 10). Nevertheless, some of the variation in the published data for different populations probably reflects the use of different diagnostic criteria by the investigators rather than a real difference.

\section{Protostylid}

Bolk [53], adopted the term "paramolar cusps" for supernumerary cusps occurring on the buccal surfaces of second and third molars. He believed that the paramolar cusps were derived from supernumerary teeth which had become fused with the permanent molars during their development. In 1945, Dahlberg proposed that the term "protosylid or parastyle" be used to refer to all anomalous cusps on the buccal surface of both the maxillary and mandibular premolars and molars. However, he did point out that the presence of a protostylid should not be considered to be an example of atavism [54].

The protostylid trait can range from a shallow depression through pits and grooves of varying depths, to tubercles and cusps with and without apical independence. Bilateral symmetry of this trait is common and it is usually seen in the form of a buccal pit; while expression as a cusp is rare [5, $16,44]$. The protostylid continuum was standardized into seven classes by Dahlberg [44]. A simplified index proposed by Snyder and co-workers [16] has also remained popular.

The protostylid trait was reported to be more common on primary than permanent molars [55]. It is supported by our study because for southern Chinese, the prevalence in the primary dentition was as high as $93.7 \%$ (Part IV of this paper series), while in the permanent dentition the prevalence was only $37.5 \%$ (Table 1). It has also been found that the protostylid trait always appears on the permanent tooth which replaces a primary molar which also exhibited the trait. However, the reverse does not always occur [54, 55].

In the primary dentition the protostylid trait is found on the buccal surface of the protocone of the mandibular second molar. As the protostylid is a genetic structure of the architecture of the primary dentition, the primary mandibular second molars can be expected to manifest the trait to a greater extent than the first primary molar and in turn the trait has a 
decreasing chance of occurring on the first, second, and third molars of the permanent dentition [54].

Suzuki and Sakai [56] reported that $18.5 \%$ of their 108 Japanese subjects had protostylid in varying degrees of prominence, and of these $65 \%$ had the Carabelli's cusp on their permanent maxillary molars. An inter-relationship between prostostylid and Carabelli's trait was also noted in the present study (Tables 6 and 7).

In the primary dentition, the protostylid trait occured in more than $40 \%$ of Mongoloid children, while in nonMongoloid populations the occurrence was less than $20 \%$ (Part IV of this paper series). Therefore, the protostylid trait has been regarded as a characteristic feature of the Mongoloid dentition [57]. By contrast, Dahlberg [20] suggested that when the mandibular first permanent molar tooth was considered, this trait had a tendency to occur more commonly in Caucasians than Mongoloids, and was rarely seen in $\mathrm{Ne}-$ groids. Furthermore, Dahlberg [44] indicated that living Aleuts have no prostostylid cusp or pit, as reported by Morrees [5], and that their condition was "a reflection of admixture". However, the figures showed on Table 11 seem to indicate that some Mongoloids, including southern Chinese, have higher prevalences of protostylid trait than Caucasians. Moreover, the prevalence of the cusp type of the protostylid trait found in this study $(10.1 \%)$ was higher than for other ethnic groups. Nevertheless, only two studies involving Caucasians were available for comparison.

Since the criteria in each study used to investigate the prevalence of the four dental trait varied, it is difficult, without careful reconsideration of the diagnostic criteria, and possibly re-analysis of the data in respect of each trait, to make valid comparisons between the studies. This further supports the notion of developing universally accepted criteria for the various dental traits and the subtypes.

\section{CONCLUSION}

From the findings of this study it was determined that southern Chinese children have a lesser degree of shoveling than the other Mongoloid groups, including other Chinese populations. The prevalence of the cusp type of Carabelli's trait in southern Chinese was higher than the other Mongoloids, and the prevalence of the cusp type of protostylid trait was even higher than for other ethnic groups. Therefore, it may be appropriate to consider semi-shovel shaped maxillary incisors and the protostylid cusp on the mandibular molars as being characteristics of the permanent dentition of southern Chinese children.

\section{REFERENCES}

[1] Dahlberg AA. The changing dentition of man. J Am Dent Assoc 1945; 32: 676-90.

[2] Hanihara K. Crown characters of the deciduous dentition of Japanese-American hybrids. Dental Anthropology. Oxford: Pergamon Press 1963; pp. 105-24.

[3] Weidenreich F. The dentition of Sinanthropus Pekinensis. A comparative odontography of the homanids. Palaeontologia Sinica New Series No.1, Peking 1937.

[4] Hrdlicka A. Shovel shape teeth. Am J Phys Anthropol 1920; 3: 429-66.

[5] Moorrees CFA. The Aleut Dentition. Boston: Harvard University Press 1957 ; 36-41.

[6] Carbonell VM. Variation in the frequency of shovel-shaped incisors in different populations. In: Dental Anthropology. Brothwell,
DR, Ed. Symposium of the Society for the study of Human Biology. New York: Pergamon Press 1963: Vol. 1: 211-34.

[7] Turner CG. Advances in the dental search for native American origins. In: Peopling of the Americas. XI Symposium Int Congress Anthropological and Ethnological Sciences 1983.

[8] Carabelli G von. Systematisches Handbuch der Zahnheikunde. Braumüller und seidel, Wien 1842.

[9] Keith A. Problems relating to the teeth of the earlier forms of prehistoric man. Proc Roy Soc Med 1913; 6: 103-24.

[10] Gregory WK, Hellman M. The dentition of Dryopithecus and the origin of man. Anthropol Pap Am Mus Nat Hist 1926; 28: 1-123.

[11] Tratman EK. Three-rooted lower molars in man and their racial distribution. Br Dent J 1938; 64: 264-74.

[12] Pederseon PO. The East Greenland Eskimo dentition. Numerical variations and anatomy. Meddelelser om Gronland BD $142 \mathrm{Nr} 3$. Reitzels Forlag, Copenhagen 1949.

[13] Turner CG. Three rooted mandibular first permanent molars and the question of American Indians origins. Am J Phys Anthropol 1971; 34(2): 229-42.

[14] Meacham W. On the ethno-linguistic identity of the ancient Yueh. Symposium on evolution of Yueh (Cantonese) people and languages: qualitative and quantitative approach. Hong Kong 1993.

[15] Hrdlička A. Future studies on tooth morphology. Am J Phys Anthropol 1921; 4: 141-76.

[16] Snyder RG, Dahlberg AA, Snow CC, Dahlberg T. Trait analysis of the dentition of the Tarahumara Indians and Mestizos of the Sierra Madre Occidental, Mexico. Am J Phys Anthropol 1969; 31: 65-76.

[17] Ooshima T, Ishida R, Mishima K, Sobue S. The prevalence of development anomalies of teeth and their association with tooth size in the primary and permanent dentition of 1650 Japanese children. Int J Pediatr Dent 1996; 6: 87-94.

[18] Tratman EK. Indo-European racial stocik with the Mongoloid racial stock. Dent Rec 1950; 70: 63-88.

[19] Jien SS. The Chinese dentition. II. Shovel incisors, Carabelli's cusps, groove patterns, cusp numbers, and abnormalities in morphology of the permanent teeth. Taiwan Yi Xue Hui Za Zhi 1970; 69: 264-71.

[20] Dahlberg AA. The dentition of American Indian. In: Laughlin WS, Ed. The Physical Anthropoly of the American Indian. New York: Viking Fund 1951.

[21] Dahlberg AA, Mikkelsen O. The shovel-shaped character in the teeth of the Pima Indians. Am J Phys Anthropol 1947; 5: 234-47.

[22] Dahlbert AA, Kirveskari P, Dahlberg H. The Pima Indian studies of the inheritance of dental morphological traits. In: Kurten B, Ed. Teeth: Form, Function and Evolution. New York: Columbia University Press 1982: pp. 292-8.

[23] Scott GR, Potter RH, Noss JF, Dahlberg AA, Dahlberg T. The dental morphology of Pima Indians. Am J Phys Anthropol 1983; 61: 13-31.

[24] Berry AC. The anthropological value of minor variants of the dental crown. Am J Phys Anthropol 1976; 45: 257-68.

[25] Irish JD. Characteristic high- and low-frequency dental traits in sub-Saharan African populations. Am J Phys Anthropol 1997; 102:455-67.

[26] Lasker GW. Observations on the teeth of Chinese born and reared in China and America. Am J Phys Anthropol 1945; 3: 129-50.

[27] Ling JYK, Wong WK. Incisal morphology of southern Chinese. Open Anthropol J 2008; 1: 19-25.

[28] Scott GR, Dahlberg AA. Microdifferentiation in tooth crown morphology among Indians of the American Southwest. In: Kurten B, Ed. Teeth:Form, Function and Evolution. New York: Columbia University Press 1982; pp. 259-92.

[29] Kharat DU, Saini TS, Mokeem S. Shovel-shaped incisors and associated invagination in some Asian and African populations. J Dent 1990; 18(4): 216-20.

[30] Hanihara K. Some crown characters of the deciduous incisors and canines in Japanese hybrids. J Anthropol Soc Nippon 1965; 72: 111.

[31] Jorgensen KD. The deciduous dentition: a descriptive and comparative anatomical study. Acta Odont Sand 1956: 69:264-71.

[32] Berry AC. Anthropological and family studies on minor variations of the dental crown. In: Butter PM, Joysey KA, Eds. Development, function and evolution of teeth. Acdemic Press: London 1978: pp. 81-98.

[33] Kornhof CAW. Morphogenetical aspects of human upper molars. Academic Dissertation, University of Utrecht 1960. 
[34] Jeanselme E. Du tubercule de Carabelli chez I'homme anx périodes paleolithique et néolithique dans I'antiquite et au moyen age. Soc Anthropol Paris 1917; 8: 121-38.

[35] McCowan TD, Keith A. The stone age of Mount Carmel. Oxford: Oxford University Press 1939; Vol II.

[36] Robinson JT. The dentition of the Australopithecinae. Transvaal Museum Memoir, no.9, Pretoria, 1956.

[37] Dietz VH. A common dental morphotropic factor. The Carabelli cusp. J Am Dent Assoc 1944; 31: 784-9.

[38] Lasker GW. Genetic analysis of racial traits of the teeth. Cold Spring Harbour Sympos Quan Biol 1951; 15: 191-203.

[39] Kieser JA. An analysis of the Carabelli trait in the mixed deciduous and permanent human dentition. Arch Oral Biol 1984; 29(6): 4036.

[40] Scott GR, Turner CG. The anthropology of modern human teeth: dental morphology and its variations. Cambridge: Cambridge University Press 1997; pp. 197-201.

[41] Kraus BS. Carabelli's anomaly of the maxillary molar teeth; observations on Mexicans and Papago Indians and an interpretation of the inheritance. Am J Hum Genet 1951; 3: 348-55.

[42] Goose DH, Lee GTR. The mode of inheritance of the Carabelli trait. Hum Biol 1971; 43: 64-9.

[43] Alvesalo L, Nuutila M, Portin P. The cusp of Carabelli. Occurrence in first upper molars and evaluation of its heritability. Acta Odontol Scand 1975; 33: 191-7.

[44] Dahlberg AA. Analysis of the American Indian Dentition. Dental Anthropology. London: Pergamon Press 1963; pp. 149-77.

[45] Hsu JW, Tsai PL, Hsiao TH, et al. The effect of shovel trait on Carabelli's trait in Taiwan Chinese and Aboriginal populations. J Forensic Sci 1997; 42: 802-6.

[46] Khraisat A, Taha ST, Jung RE, Hattar S, Smadi L, Al-Omari IK, Jarbawi M. Prevalence, association, and sexual dimorphism of Carabelli's molar and shovel incisor traits amongst Jordanian population. Odontostomatol Trop 2007; 30(119): 17-21.

[47] Tsuji T. Incidence and inheritance of he Carabelli's cusp in a Japanese population. Jap J Hum Genet 1958; 3: 21-31.

[48] Turner CG. The dentition of Arctic Peoples. Doctoral thesis, University of Wisconson, Madison, USA 1967.

[49] Reddy VR. Carabelli's anomaly in a Karnataka town of south India. Acta Anthropogenet 1983; 7(1): 53-74.

[50] Hsu JW, Tsai PL, Hsiao TH, et al. Ethnic dental analysis of shovel and Carabelli's traits in a Chinese population. Aust Dent J 1999; 44: 40-5.

[51] Ishida R, Mishima K, Adachi C, et al. Frequency of the developmental disturbances of tooth structure. Shoni Shikagaku Zasshi 1990; 28(2): 466-85.

[52] Kondo S, Townsend GC. Associations between Carabelli trait and cusp areas in human permanent maxillary first molars. Am J Phys Anthropol 2006; 129(2): 196-203.

[53] Bolk L. Supernumerary teeth in the molar region in man. Dent Cosmos 1914; 56: 154-67.

[54] Dahlberg AA. The evolutionary significance of the protostylid. Am J Phys Anthropol 1950; 8: 15-25.

[55] Hanihara K. Criteria for classification of crown characters of the human deciduous dentition. J Anthropol Soc Nippon 1961; 69: 2745.

[56] Suzuki M, Sakai T. On the protostylid of Japanese. J Anthropol Soc Nippon 1954; 63: 81-4.
[57] Hanihara K. Morphological pattern of the deciduous dentition in the Japanese American hybrids. J Anthropol Soc Nippon 1968; 76: 114-21.

[58] Kikuchi S. On the difference in the incisor shape in Japanese and European subjects. Forschr Kieferorthop 1967; 28: 351-60.

[59] Bang G, Hasund A. Morphologic characteristics of the Alaskan Eskimo dentition I: Shovel-shape of incisors. Am J Anthopol 1971; 335: 43-8.

[60] Scott GR. Dental morphology: a genetic study of American white families and variation in living Southwest Indians. Doctoral dissertation, Arizona State University, Tempe, Arizona 1973.

[61] Kieser JA, Preston CB. The dentition of the Lengua indians of Paraguay. Am J Phys Anthropol 1981; 55: 485-90.

[62] Koski K, Hantala E. On the frequency of shovel-shaped incisors in the Finns. Am J Phys Anthropol 1952: 10: 127-32.

[63] Kaul V, Prakash S. Morphological features of Jat dentition. Am J Phys Anthropol 1981; 54: 123-7.

[64] Saunders SR, Mayhall JT. Developmental patterns of human dental morphological traits. Arch Oral Biol 1982; 27: 45-9.

[65] Hsu JW, Tsai P, Liu K, Ferguson D. Logistic analysis of shovel and Carabelli's tooth traits in a Caucasoid population. Forensic Sci Int 1997; 89: 65-74.

[66] Edgar HJ, Lease LR. Correlations between deciduous and permanent tooth morphology in a European American sample. Am J Phys Anthropol 2007; 133(1): 726-34.

[67] Escobar V, Conneally PM, Lopez C. The dentition of the Queckchi Indians. Anthropological aspects. Am J Phys Anthropol 1977; 47: 443-51.

[68] Liu KL. Dental condition of two tribes of Taiwan aborigines - Ami and Atayal. J Dent Res 1977; 56: 117-27.

[79] Ling JYK. A morphometric study of the dentition of 12 year old Chinese children in Hong Kong. PhD Thesis, The University of Hong Kong 1992.

[70] Sharma JC. Dental morphology and odontometry of the Tibetan immigrants. Am J Phys Anthropol 1983; 61: 495-505.

[71] Guo L, Sun DL, Ren L, et al. A comparative morphologic study of Carabelli cusp between Chinese and Japanese students. Shanghai Kou Qiang Yi Xue 1995; 4: 66-7.

[72] Meredith HV, Hixon EH. Frequency, size, and bilateralism of Carabelli's tubercle. J Dent Res 1954; 33: 435-440.

[73] Rosenzweig KA, Zilberman Y. Dental morphology of Jews from Yemen and Cochin. Am J Phys Anthropol 1967; 26: 15-21.

[74] Keene HJ. The relationship between Carabelli's trait and the size, number and morphology of the maxillary molars. Arch Oral Biol 1968; 13: 1023-5.

[75] Joshi MR, Godiawala RN, Dutia A. Carabelli's trait in Hindu children from Gujarat. J Dent Res 1972; 51: 706-11.

[76] Kirveskari P. Morphological traits in the permanent dentition of living Skolt Lapps. Proc Finn Dent Soc 1974; 70(Suppl II): 1-90.

[77] Thomas CJ, Kotze TJ, Nash JM. The Carabelli trait in the mixed deciduous and permanent dentitions of five South African populations. Arch Oral Biol 1986; 31: 145-7.

[78] Townsend GC, Martin NG. Fitting genetic models to Carabelli trait data in South Australian twins. J Dent Res 1992; 71: 403-9.

[79] Tsai PL, Hsu JW, Lin LM, Liu KM. Logistic analysis of the effects of shovel trait on Carabelli's trait in a Mongoloid population. Am J Phys Anthropol 1996; 100: 523-30. 